\title{
Reimagining the Family of King Charles I in Nineteenth-Century British Painting
}

\author{
Catriona Murray
}

History of Art, University of Edinburgh, Edinburgh, UK

Email: c.a.murray@ed.ac.uk

\begin{abstract}
The nineteenth century represents a formative period for the development of historical consciousness in Britain, with texts and, increasingly, images shaping perceptions of the past. This article examines how Stuart history was interpreted and experienced, through a series of historical genre paintings of King Charles I and his family. It explores how Anthony van Dyck's depiction of politicized domesticity in royal portraiture was revised and reworked in these later images. Reimagining Stuart family life, they extended processes of remembering, enlisting audiences in an active, participatory engagement with the past. Probing temporal, visual, and verbal alignments and connections, the article contributes further dimensions to the understanding of historical representation. It argues that these paintings stirred the viewer's intellectual, emotional, and associative responses to encourage a sense of proximity. Establishing an episodic narrative, they initiated processes of recollection and recognition, they reflected sympathetic historiographies, and they encouraged a shared community with their pictorial protagonists. By so doing, nineteenth-century artists diminished historical distance and fashioned a familiarized past.
\end{abstract}

In 1632, Charles I commissioned one of the defining images both of his reign and of his government, 'One greate peece of $\mathrm{O}[\mathrm{u}] \mathrm{r}$ royall selfe, Consort and children' (see Figure 1). In Van Dyck's monumental group portrait, private and public roles coalesce. Domestic imagery is employed to support political rhetoric, with the king figured exercising his paternal authority over both

\footnotetext{
${ }^{1}$ Julia Marciari Alexander, 'Portraiture and royal family ties: kings, queens, princes, and princesses in Caroline England', in Naomi J. Miller and Naomi Yavneh, eds., Gender and early modern constructions of childhood (Farnham and Burlington, VT, 2011), p. 210.

(C) The Author(s), 2021. Published by Cambridge University Press. This is an Open Access article, distributed under the terms of the Creative Commons Attribution-NonCommercial licence (http://creativecommons.org/ licenses/by-nc/4.0), which permits non-commercial re-use, distribution, and reproduction in any medium, provided the original article is properly cited. The written permission of Cambridge University Press must be obtained prior to any commercial use.
} 


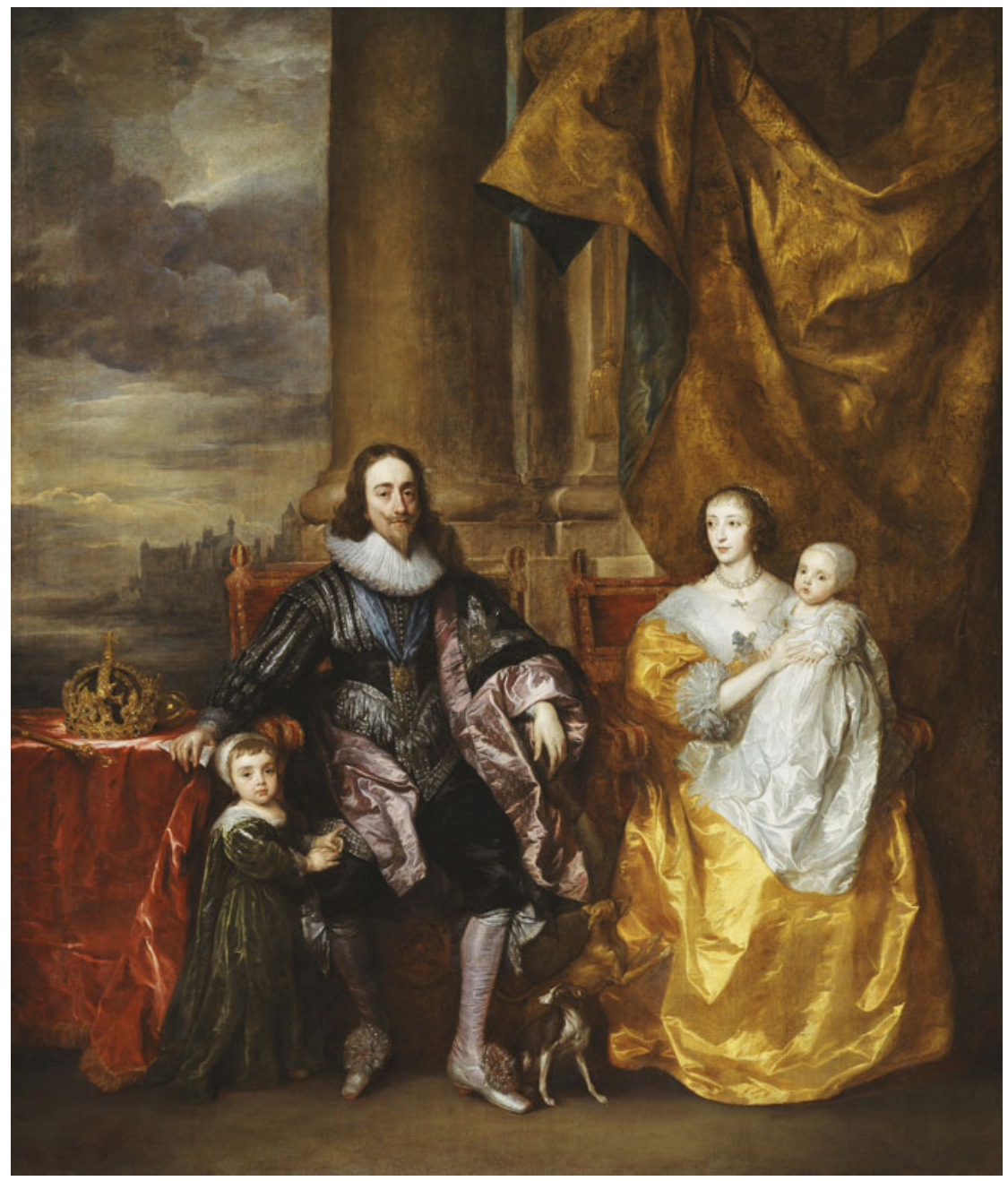

Figure I. Anthony van Dyck, Charles I and Henrietta Maria with their two eldest children, Prince Charles and Princess Mary, 1632. Oil on canvas, $303.8 \times 256.5 \mathrm{~cm}$. Royal Collection Trust. (C) Her Majesty Queen Elizabeth II 202I.

his family and his subjects. Charles sits, his right arm enclosing his young heir, who rests a small hand on his father's knee, pointing up towards the king. Henrietta Maria, in turn, props up the figure of her baby daughter and contemplates her husband with an intent regard. This air of immediacy and informality, however, belies the painting's complex allusions. Subtle networks of exchanged gestures and glances connect the family members, emphasizing affective bonds while also underlining hierarchical relationships. Even the presence of two twitchy Italian greyhounds, representative of fidelity and obedience, support this projection of a devoted and well-ordered household. 
Yet this apparent intimacy is supplanted by a grandiose stage-set, dressed with the trappings of Stuart power. To Charles's right, placed upon a table swathed in crimson, sit the crown, sceptre, and orb, while beyond, discernible through the murky clouds of an unsettled sky are the silhouettes of Westminster Hall and the Parliament House, the administrative and legislative centres of the kingdom. By inference, the harmony pictured in this royal family grouping extends outward to the realm and its people. Charles is proclaimed as a father king, who guides and protects the common good as he does his children. His depiction as loving paterfamilias supports his status as pater patriae.

The 'greate peece' has been designated 'one of the most important texts of early modern kingship'. ${ }^{2}$ Indeed, images of Charles I's family were to become central to the representation of his reign until its premature end, following his execution in 1649. Their combination of domestic associations and authoritarian overtones can be discerned in royal family portraits throughout the seventeenth, eighteenth, and nineteenth centuries. ${ }^{3}$ This article will consider a different legacy, however, exploring how Van Dyck's depiction of politicized domesticity in Stuart portraiture was revised and reworked in a number of nineteenth-century historical genre paintings. By so doing, it considers how these later compositions materialized the Caroline past for modern audiences, assessing the role of the visual in the historical imagination and probing shifting processes of remembering. Reimagining Stuart family life, these nineteenth-century paintings constituted multi-layered mediators through which viewers might look both back and forward. Enlisting audiences in an involved, participatory engagement with the past, they served to negate temporal distance and to promote historical proximity. Analysis of these overlooked images, therefore, offers new insight into encounters and relationships with the past, during a critical period in the development of historical consciousness in Britain. ${ }^{4}$

Historical perception is rarely static but alters and fluctuates. Throughout time, the present has renegotiated its relationship with the past. ${ }^{5}$ of course, the appropriation and manipulation of Charles I's image was nothing new. With the publication of his autobiography, Eikon Basilike (1649), just days after the king's execution, his representation was popularized, exposed to an image-making process which was 'collective, collaborative and participatory'. The post-Restoration regime celebrated Charles as saint-like martyr, while the

\footnotetext{
${ }^{2}$ Kevin Sharpe, Image wars: promoting kings and commonwealths in England, 1603-1660 (New Haven, CT, and London, 2010), p. 206.

${ }^{3}$ See, for example, Peter Lely, James and Anne, duke and duchess of York, with their daughters, Princess Mary and Princess Anne, begun c. 1667, completed c. 1680, oil on canvas, 168.6 x $194 \mathrm{~cm}$, London, Royal Collection; Allan Ramsay, Queen Charlotte and her two eldest sons, c. 1764-9, oil on canvas, 247.8 x $165 \mathrm{~cm}$, London, Royal Collection; Franz Xaver Winterhalter, The royal family in 1846, 1846, oil on canvas, 250.5 x $317.3 \mathrm{~cm}$, London, Royal Collection.

${ }^{4}$ Rosemary Mitchell, Picturing the past: English history in text and image, 1830-1870 (Oxford, 2000), p. 2.

${ }^{5}$ Mark Salber Phillips, On historical distance (New Haven, CT, and London, 2013), p. 59.

${ }^{6}$ Elizabeth Skerpan-Wheeler, 'Eikon Basilike and the rhetoric of self-representation', in Thomas Corns, ed., The royal image: representations of Charles I (Cambridge, 1999), p. 135.
} 
Jacobites, in turn, adopted him as an icon of suffering and hope. ${ }^{7}$ Later, parallels between the English and French Revolutions recast his biography as cautionary, a precedent from which both royalists and republicans might learn. ${ }^{8}$ In the nineteenth century, Charles's portrayal continued to acquire new meanings. The English Revolution encroached on the Victorian mindset like no other historical struggle. ${ }^{9}$ It was perceived as the source from which civil liberties and the constitutional monarchy originated, while its controversies had left long-standing political fissures that still troubled the nation. ${ }^{10}$ At the same time, the Caroline era also supplied an appealing prototype for nineteenthcentury family life. The Victorian cult of domesticity exalted home and household as the foundations of civilized society. ${ }^{11}$ In Van Dyck's images of Charles I and his family, viewers saw a historical model for their own idealized private lives. ${ }^{12}$ Yet, touched by his depiction of royal familial harmony, they also recognized a warning from the past. Political and domestic concerns were intertwined in readings of these images and viewers knew how the story ended. Accordingly, historical genre paintings of the royal family serialized the tragedy of the hapless Stuarts, connecting a glimpse of 'history-in-themaking with its final significance.'. ${ }^{13}$

In the nineteenth century, understanding of the past was formed through an unprecedented expansion of historical culture. A new awareness permeated the middle classes in the first half of the century, with a historically minded mass audience developing by its end. ${ }^{14}$ In a democratization of historical experience, this awareness was shaped not only through the texts of such distinguished scholars as Thomas Babington Macaulay and Thomas Carlyle but also through popular volumes, works of fiction, and, importantly, through visual culture. ${ }^{15}$ The nineteenth-century visualization of history presented new ways of viewing the past. A pictorial historiography developed, made up of

\footnotetext{
${ }^{7}$ Lois Potter, 'The royal martyr in the Restoration: national grief and national sin', in Corns, ed., The royal image, p. 243; Laura Lunger Knoppers, 'Reviving the martyr king: Charles I as Jacobite icon', in Corns, ed., The royal image, p. 264.

${ }^{8}$ Beth S. Wright, Painting and history during the French Restoration: abandoned by the past (Cambridge, 1997), pp. 92-5; Rachel Hammersely, The English republican tradition and eighteenthcentury France: between the ancients and the moderns (Manchester, 2010), pp. 159-61.

${ }^{9}$ Timothy Lang, The Victorians and the Stuart heritage: interpretations of a discordant past (Cambridge, 1995), p. xii; Roy Strong, And when did you last see your father? The Victorian painter and British history painting (London, 1978), p. 137; Richard Ollard, The image of the king: Charles I and Charles II (London, 2000), 193.

${ }^{10}$ Laura Lunger Knoppers, 'The English Revolution in nineteenth-century British and French literature and art', in Michael J. Braddick, ed., The Oxford handbook of the English Revolution (Oxford, 2015), p. 537.

${ }^{11}$ Anthony Wohl, 'Introduction', in Anthony Wohl, ed., The Victorian family: stresses and structures (London, 1978), p. 9.

${ }^{12}$ Laura Lunger Knoppers, Politicizing domesticity: from Henrietta Maria to Milton's Eve (Cambridge, 2011), p. 1.

${ }^{13}$ Wright, Painting and history during the French Restoration, p. 81.

${ }^{14}$ Mitchell, Picturing the past, p. 2.

${ }^{15}$ Ibid., p. 2; Knoppers, 'The English Revolution in nineteenth-century British and French literature and art', p. 547.
} 
retrospective artistic representations, both painted and printed. These images were reductive, abridging history into a series of dramatic scenes but they were also accessible and immediate. What is more, they shifted the onus of interpretation from the historian to the viewer, opening up historical meaning. ${ }^{16}$ Mark Salber Phillips has asserted that historical representations produce different effects of distance, mediating our encounters with the past. ${ }^{17}$ The spectrum runs from remoteness to proximity. As he argues, the detachment of the former offers clarity and perspective, while the intimacy of the latter encourages insight and connection. ${ }^{18}$ Phillips identifies four dimensions of representation that shape our experience of time: form, affect, ideology, and cognition. ${ }^{19}$ My aim here is to complement and supplement this analysis, exploring how nineteenth-century visual culture fashioned historical proximity by reaching beyond the frame to form a series of connections. Adapting Phillips's linear conception of distance, I argue that images of Charles I and his family lie at the centre of a network, where the audience's intellectual, emotional and associative responses intersect to encourage a sense of intimacy. By simultaneously invoking recognition, sympathy and communality, these paintings reshaped time. Relationships between original and derivative, text and image, past and present encouraged an active viewing and rendered Stuart history close-up.

\section{II}

Commenting in 1879 on Van Dyck's portraits of Charles I, one of the artist's first English biographers, Percy Rendell Head, remarked: 'On the countenance of mournful dignity there rests a shadow of trouble past and to come, which, read by the light of history, seems like a revelation of the future. ${ }^{20}$ In his later study of the painter, Lionel Cust, director of the National Portrait Gallery, went further:

It is the Charles I of Van Dyck whom the historian pictures to himself, defying the House of Commons, receiving the news of Naseby or Edgehill, the Captive of Hampton Court or Carisbrooke, or the royal martyr, pacing with undiminished dignity and pride through the snowy morning to the last scene of the scaffold of Whitehall. For all these scenes Van Dyck prepares the illustration. ${ }^{21}$

Both commentaries illustrate the extent to which Van Dyck's portrayal of the king had penetrated nineteenth-century historical memory. Indeed, Head

\footnotetext{
${ }^{16}$ Maurice Samuels, 'Illustrated historiography and the image of the past in nineteenth-century France', French Historical Studies, 26 (2003), pp. 253-80, at p. 275.

${ }^{17}$ Phillips, On historical distance, p. 3; Mark Salber Phillips, 'Distance and historical representation', History Workshop Journal, 57 (2004), p. 125.

${ }^{18}$ Phillips, On historical distance, p. 2.

${ }^{19}$ Ibid., p. 14.

${ }^{20}$ Percy Rendell Head, Van Dyck (London, 1879), p. 63.

${ }^{21}$ Lionel Cust, Anthony van Dyck: an historical study of the life and works (London, 1900), p. 97.
} 
acknowledges the significant role of the artist in constructing an alluring and enduring image of the Caroline royal family, pronouncing Van Dyck largely responsible for the strangely passionate affection with which a large section of the English people [have] long cherished the remembrance of the unhappy and unprofitable Stuarts. ${ }^{22}$ Van Dyck's royal portraits were displayed in public collections and temporary exhibitions, while reproductions entered the middle-class home as engravings, book illustrations, and images in periodicals. ${ }^{23}$ To nineteenth-century audiences, then, his paintings were agents for narratives and visions of the past, while simultaneously becoming embedded with meanings and resonances beyond their original situations and intentions. In retrospect, Van Dyck's works were re-read and re-remembered. The royal portraits were now premonitions, pictorial presentiments of the Caroline tragedy. Indeed, in Sir Walter Scott's historical novel, Woodstock (1826), Cromwell, himself, is portrayed brooding over a Van Dyck portrait of the late king only to predict that 'our grandchildren, while they read his history, may look on his image, and compare the melancholy features with the woful [sic] tale. ${ }^{24}$ Historical genre paintings of the Stuarts extended this process of reimagining. Some played upon the audience's knowledge of what was to come, presenting them with a fictional scene of Stuart domestic harmony and happiness soon to be shattered, while others pictured the next chapter in the story, visualizing the forced separation of the royal family and foreshadowing the imminent loss of its head. Perceptions of Van Dyck's compositions and the advent of their nineteenth-century successors point to a cyclical relationship, where retrospective interpretations of his original pictures inspired a series of derivative 'spin-off' images. These pictorial scions, in turn, came to influence readings of, and responses to, their prototypes. Significantly, this process illustrates the formation of an unfolding, episodic Stuart historical drama in the public imagination. Indeed, for those later pictures, recognition both of the situational present and of its temporal connections was central to imparting historical proximity.

\footnotetext{
${ }^{22}$ Head, Van Dyck, p. 64.

${ }^{23}$ Throughout the nineteenth century, exhibitions of old Master paintings were regularly held at public museums, private galleries, mechanics' institutes, and by learned societies across Britain - see Amy M. Von Lintel, 'Art history as spectacle: blockbuster exhibitions in 1850s England', in Andrew Graciano, ed., Exhibiting outside the academy, salon and biennial, 1775-1999: alternative venues for display (Burlington, VT, and Farnham, 2015). In January 1887, London's Grosvenor Gallery opened for its major Van Dyck exhibition, including his portrait of The three eldest children of Charles I (1635) on loan from the queen; see 'Van Dyck at the Grosvenor Gallery', Times, 30370, 6 Dec. 1881, p. 11. S. C. Hall's series of engravings, The royal gallery of art ancient and modern: engravings from the private collections of Her Majesty the Queen and His Royal Highness Prince Albert (London, 1854), includes reproductions of a number of Van Dyck's royal family portraits. One of the frontispieces to volume VIII of Agnes Strickland's Lives of the queens of England (London, 1845), is an engraved vignette of the 'greate peece'. Art periodicals regularly published illustrations of Van Dyck's royal portraits - see, for example, 'The royal pictures', Art Journal, 24 (Dec. 1856), pp. 360-2; 'Van Dyck', Magazine of Art, 5 (Jan. 1882), pp. 422-30; 'The picture gallery of Charles I', Portfolio: Monographs on Artistic Subjects (Jan. 1896), pp. 5-126.

${ }^{24}$ Walter Scott, The works of Walter Scott: Woodstock or The Cavalier (4 vols., Zwickau, 1826), I, p. 191.
} 
The complex sequence of invention and reinvention, from Van Dyck's initial pictorial construction of the Stuart family to the nineteenth-century painters' later visual reimagining, is pulled into focus in John Everett Millais's oil sketch for a lost composition, Charles I and his son in the studio of Van Dyck (1849, see Figure 2). In the early 1840s, two other artists, Ferdinand Pickering and Samuel West, had exhibited paintings with a similar theme. Both Pickering's A visit to Vandyck (1841) and West's Charles I receiving instruction in drawing from Rubens, whilst sketching the portraits of his queen and child (1842) appear to have emphasized the king's close relationships with his court painters, while conforming to the familiar image of Charles as an involved and affectionate husband and father. ${ }^{25}$ Millais sets his scene in the artist's studio. Palette in hand, Van Dyck works on a small head-and-shoulders portrait of the king, who sits enthroned before him. The screens behind Charles, the suit of armour on display and the edge of a gilt mirror, in which the artist is reflected, all support the sense that this is a moment of artistic image-making, of artifice and pretence. Yet, leaning into the king's figure, in a tender embrace, is a young golden-haired prince, who smiles towards the painter. The gesture contributes an impression of natural feeling and informal emotion. The audience is privy not to the creation of an official state portrait but to that of an intimate keepsake - a snapshot of Caroline domestic bliss. The fatherly care and affective ties depicted in Van Dyck's canvases have been magnified. Thus, paradoxically, Millais seemingly acknowledges the court artist's agency and the construction of a Caroline family image, while accepting and conforming to succeeding sentimental narratives. The canvas on which his Van Dyck daubs is pure fantasy, reflecting not Stuart but Victorian sensibilities and reflexively highlighting Millais's own part in this painterly revision of history. Certainly, painters did not misrecognize or misunderstand dynastic representations, they consciously re-presented them. Indeed, what had been a pictorial political statement was transformed into an evolving and involving visual narrative. Representations of the Stuarts now formed a succession of scenes that depicted a present in which temporal links and alignments were inherent. In picturing Van Dyck at work, Millais signalled back to the old master's actual royal portraits. Yet, in depicting a moment of happiness, of paternal regard and filial affection, albeit an imagined one, he also motioned forward to the moments of unhappiness yet to come. Sharing in an uncomfortable awareness, audiences were drawn in through their knowledge of significances beyond the canvas itself.

Even in its title, Frederick Goodall's An episode in the happier days of Charles I (1853, see Figure 3), implicitly points towards events outside the picture frame. In this painting, Charles and his family take an idyllic cruise along the Thames on a richly decorated barge. Clad in black, a striking and ominous contrast with

\footnotetext{
${ }^{25}$ Pickering's composition was accompanied by a quotation from Horace Walpole's Anecdotes of painting in England (1762-80): 'Vandyck was lodged among the King's artists at Black friars. Thither Charles and his Queen, Henrietta Maria, often went, viewing his performances with singular delight, and frequently bespeaking pictures of themselves, their children, courtiers etc.' See Algernon Graves, The Royal Academy of Arts (8 vols., London, 1905-6), VI, p. 136.
} 


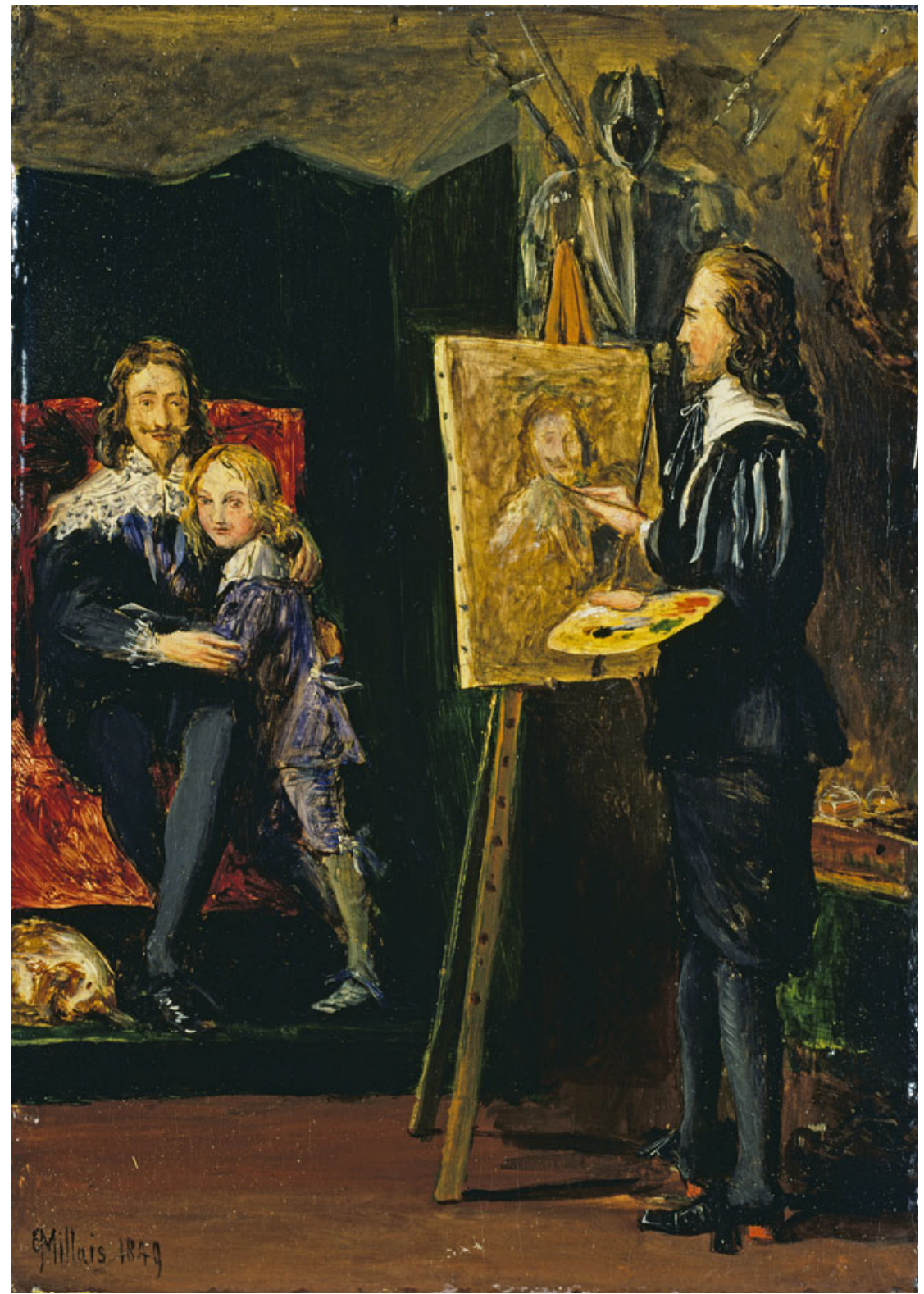

Figure 2. John Everett Millais, Charles I and his son in the studio of Van Dyck, 1849. Oil on wood, I5.9 x $11.4 \mathrm{~cm}$. Presented by Henry Vaughan 1900. Photo: Tate.

his colourfully attired wife and offspring, the king has set aside his reading to watch his children feed the swans. Leaning against the canopied tilt, the doting father surveys a charming scene. With a spaniel perched on her lap, Henrietta 


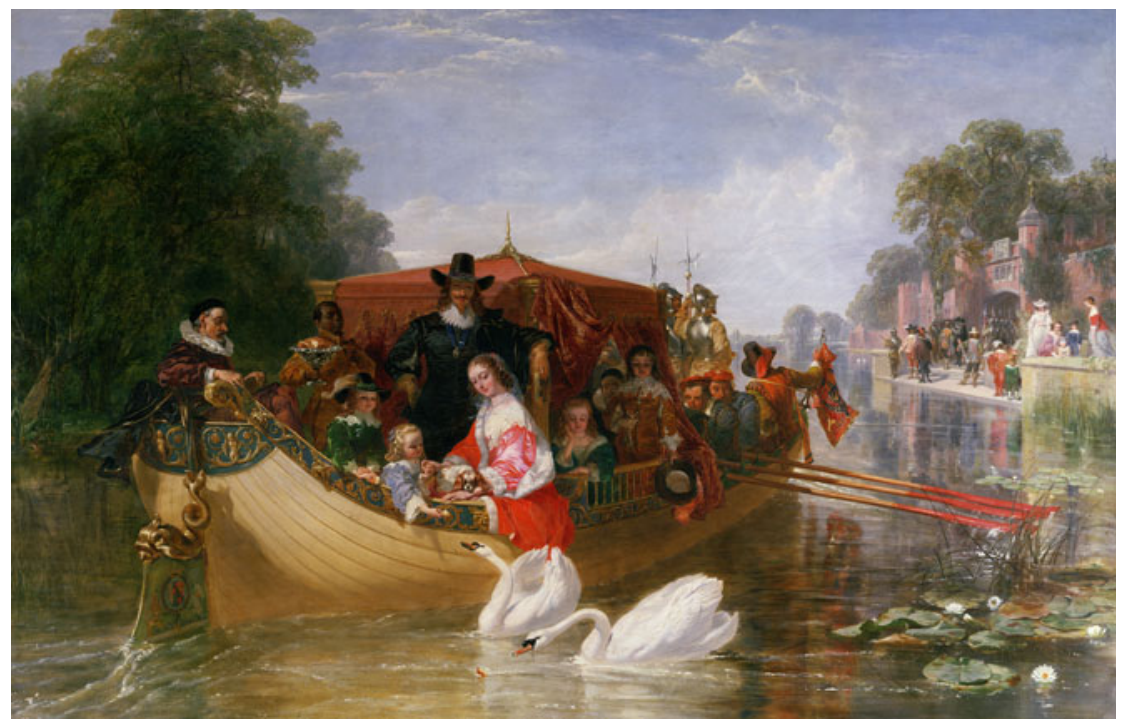

Figure 3. Frederick Goodall, An episode in the happier days of Charles I, 1853. Oil on canvas, $99.5 \times$ $153.5 \mathrm{~cm}$. Bury Art Museum \& Sculpture Centre, UK (C) Bury Art Museum \& Sculpture Centre / Bridgeman Images.

Maria gently cradles one of her daughter's hands, while the diminutive rosyfaced child offers a piece of bread to an approaching bird. The couple's other children and retainers look on serenely. Meanwhile, the oarsmen row the shallop toward its mooring, where a small crowd awaits the royal passengers. Charles, himself, is closely modelled on Van Dyck's half-length portrait type, dating from the late 1630s (1635-7, see Figure 4), which portrays the king dressed in black, the silver star of the Order of the Garter emblazoned on his cloak. One of his hands rests upon his discarded hat, the other clutches a pair of gloves - both of which Charles wears in Goodall's composition. Fidelity to his prototypes was evidently of concern to the artist, who sought permission from Queen Victoria to study Van Dyck's portraits at Windsor. ${ }^{26}$ In particular, he spent several weeks 'making studies from the Vandyck picture of "Charles, Henrietta Maria and the Children". ${ }^{27}$ In the nineteenth century, the 'greate peece' was, indeed, installed at Windsor so it is clear to which picture Goodall devoted his attention. ${ }^{28}$ With the exception of Charles, however, Goodall's portrayal of the Stuart royal family is largely invented. While the queen's form constitutes an approximation of her portraiture, the children are essentially imaginary figures, composite creations that merge Vandyckian and Victorian conceptions of childhood. The result is a mediated authenticity,

\footnotetext{
${ }^{26}$ Frederick Goodall, The reminiscences of Frederick Goodall R.A. (London and Newcastle, 1902), p. 34 .

${ }^{27}$ Ibid., p. 381.

${ }^{28}$ W. H. Pyne, The history of the royal residences (3 vols., London, 1819), I, pp. 91-2.
} 


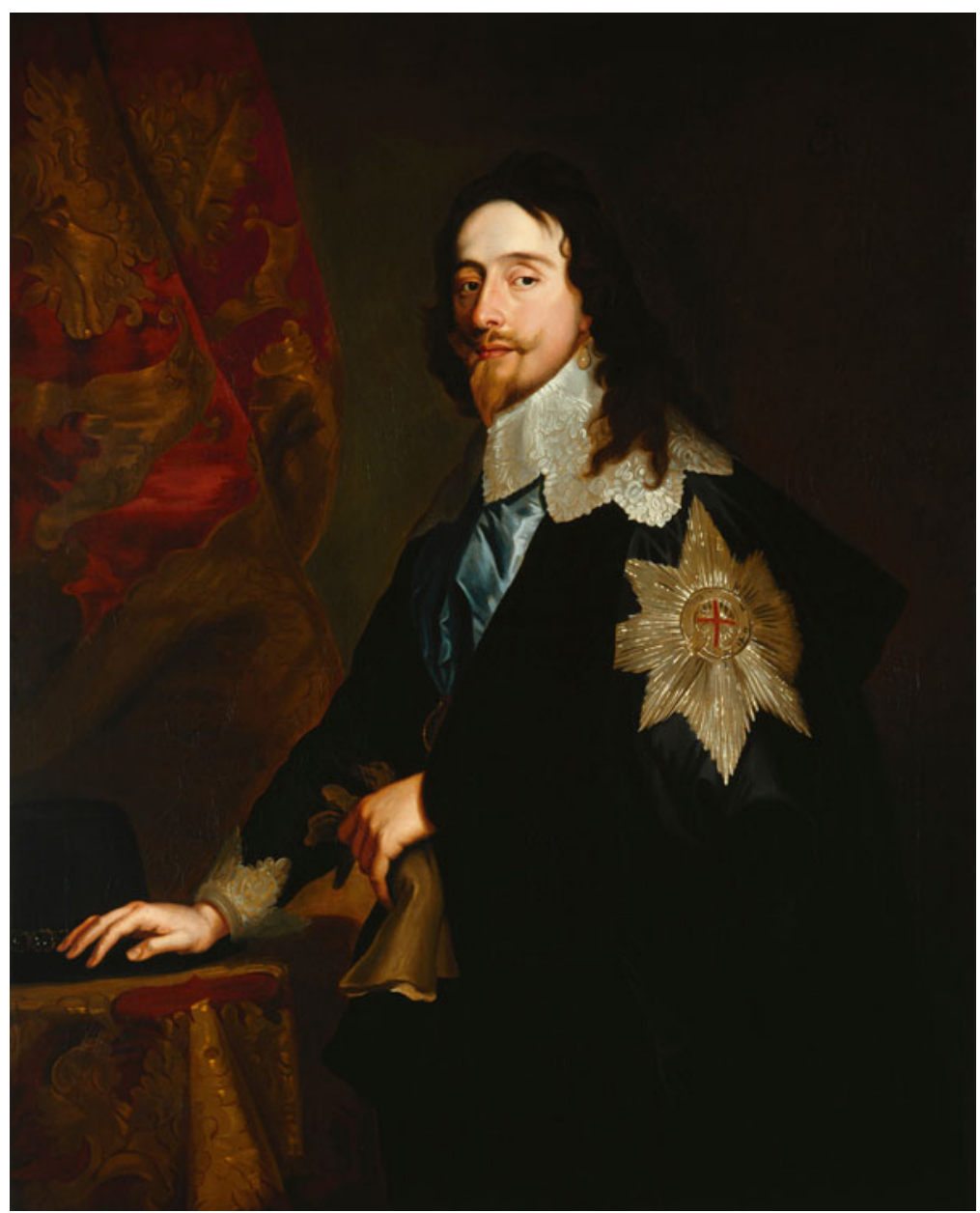

Figure 4. After Anthony van Dyck, King Charles I, 1635-7. Oil on canvas, $123.2 \times 99.1 \mathrm{~cm}$. (c) National Portrait Gallery, London.

a construction of passing historical truth that lends credence to the sentimentalized scene. Blurring the lines between fact and fiction, between imagined and actual histories, again supported a mythologized story-telling, in which relationships between past, present, and future came to the fore. This invented and heavily glossed 'episode' looks forward to impending genuine events. Indeed, such was its narrative power that it became a major plot device in W. G. Wills's play, Charles I, performed at London's Lyceum Theatre in 1872. Goodall's composition was realized in tableaux at the end of the first act. ${ }^{29}$ Commenting on his original painting, the theatre critic for The Times observed:

${ }^{29}$ Anon., 'Lyceum Theatre', Times, 27495, 30 Sept. 1872, p. 8. 
The sentiment awakened by a contemplation of this picture would lie dormant did not the imagination of the spectator wander beyond the limits of the scene presented to his eyes, until it reached the scaffold at Whitehall. It is the knowledge of the unhappiness by which the happy days were followed which gives the subject interest. ${ }^{30}$

Thus, the reviewer pinpoints the internal process through which audiences recognized the painted present and mentally realized the historical future. It is this response that, he states, 'links together the several parts' of the play's somewhat disjointed historical narrative. ${ }^{31}$ Again, the nineteenth-century public's understanding of Stuart history as a serialized progression is apparent in the critic's remarks. It was this impression that historical genre paintings drew on to engage the viewer. In looking back, artists sought to establish authenticity, appropriating and adapting Van Dyck's motifs to imbue their works with the illusion of realism. In looking forward, they imbued their compositions with pathos, encouraging the viewer to envisage actions outside the canvas, an unfortunate future passed. By so doing, audiences at once grasped the significance of what was portrayed, while also foreseeing its fallout. Historical proximity was advanced through a jarring insider knowledge.

\section{III}

Rosemary Mitchell has described how the nineteenth-century understanding of the past was shaped through a 'picturesque historiography', in which the visual was as influential as the textual and a sense of empathy was considered an aid to insight. ${ }^{32}$ Romantic in their outlook, picturesque histories dramatically reconstructed the colour and spectacle of past events, in turn, often blurring their nuances and complexities. The roots of this mode of historical imagination lie in the eighteenth century and one text, in particular, was influential in establishing a more accessible and emotive historical experience David Hume's History of England (1754-62). ${ }^{33}$ Indeed, Hume, himself, asserted that it was the responsibility of the historian to be 'interesting', to touch the reader and play upon their sympathies. ${ }^{34}$ This effect was enhanced and extended when, in 1792, the miniaturist, Robert Bowyer, undertook to produce an illustrated edition of the History. More than a hundred pictures were painted (and subsequently engraved) to accompany scenes from Hume's narrative, spanning centuries of England's past. ${ }^{35}$ In sympathy with the History's text, which was liberally interspersed with sentimental episodes from the lives of its protagonists, it was hoped that these images would serve to rouse 'the passions, to fire the mind with emulation of heroic deeds, or to inspire it with

\footnotetext{
${ }^{30}$ Ibid., p. 8.

${ }^{31}$ Ibid., p. 8.

32 Mitchell, Picturing the past, p. 16.

33 Ibid., pp. 34-5.

${ }^{34}$ Y. J. T. Greig, ed., The letters of David Hume (2 vols., Oxford, 1932), I, p. 210.

${ }^{35}$ Strong, And when did you last see your father?, p. 21.
} 
detestation of criminal actions. ${ }^{36}$ Declaring the superiority of art in promoting an immediate historical experience, Bowyer remarked: 'In many of those events, which strongly arrest the attention, there is some striking moment, the effect of which is unavoidably weakened by the mode of relating the tale...Here is the painter's advantage. What is done in an instant, his pencil as instantaneously tells. ${ }^{37}$ Bowyer's statement corresponds to a contemporary concern with the psychology of looking and the relationship between vision and the processing of knowledge. ${ }^{38}$ His high-minded scheme ultimately led to his financial ruin. ${ }^{39}$ Yet the resulting illustrations did much to create the scenery of English history, offering a body of images which later artists would repeatedly appropriate and adapt. ${ }^{40}$

This coalition of text and image would also prove formative in the refashioning process to which the Caroline royal family would be subject, as is evident from Thomas Stothard's lost painting of Charles I taking leave of his children, commissioned for Bowyer's scheme and now known through engraved copies (1794, see Figure 5). Stothard's composition centres on the conversation between Charles and his youngest son, Henry, duke of Gloucester, the day before the king's execution - a moment described in the History as follows:

Holding him on his knee, he said, 'Now they will cut off thy father's head.' At these words the child looked very steadfastly upon him. 'Mark child, what I say! They will cut off my head and perhaps make thee a king! But mark what I say! Thou must not be a king, as long as thy brothers, James and Charles are alive. They will cut off thy brothers' heads when they catch them! And thy head too, they will cut off at last! Therefore I charge thee do not be made a king by them!' The Duke, sighing, replied, 'I will be torn in pieces first!' So determined an answer from one of such tender years, filled the king's eyes with tears of joy and admiration. ${ }^{41}$

Hume's passage is virtually a direct quotation from the eye-witness account of Charles's daughter, Princess Elizabeth, which was first published just months after her father's death and frequently recited in biographies and histories thereafter. ${ }^{42}$ Stothard's image too had a life beyond its inception, widely

\footnotetext{
${ }^{36}$ Robert Bowyer, Elucidation of Mr. Bowyer's plans for a magnificent edition of Hume's History of England with a continuation by G. Gregory (London, 1795), p. 14.

${ }^{37}$ Ibid., p. 8.

${ }^{38}$ Stephen Bann, Scenes and traces of the English Civil War (London, 2020), pp. 149-50.

${ }^{39}$ T. S. R. Boase, 'Macklin and Bowyer', Journal of the Warburg and Courtauld Institutes, 26 (1963), pp. $148-77$ at p. 170.

${ }^{40}$ Ibid., p. 176.

${ }^{41}$ David Hume, The history of England (folio edition) (10 vols. 1793-1806, London), X, p. 470.

${ }^{42}$ Anon., Munday the 29th. January, 1648. A true relation of the kings speech to the Lady Elizabeth, and the duke of Gloucester, the day before his death (London, 1649), single page. Among the many texts which recount this episode are: Anon., The life and death of Charles the first king of Great Britain, France and Ireland (London, 1690); Edward Hyde, first earl of Clarendon, The history of the Rebellion and Civil Wars in England, begun in the year 1641 (Oxford, 1702); and John Adams, The flowers of modern history (London, 1796).
} 


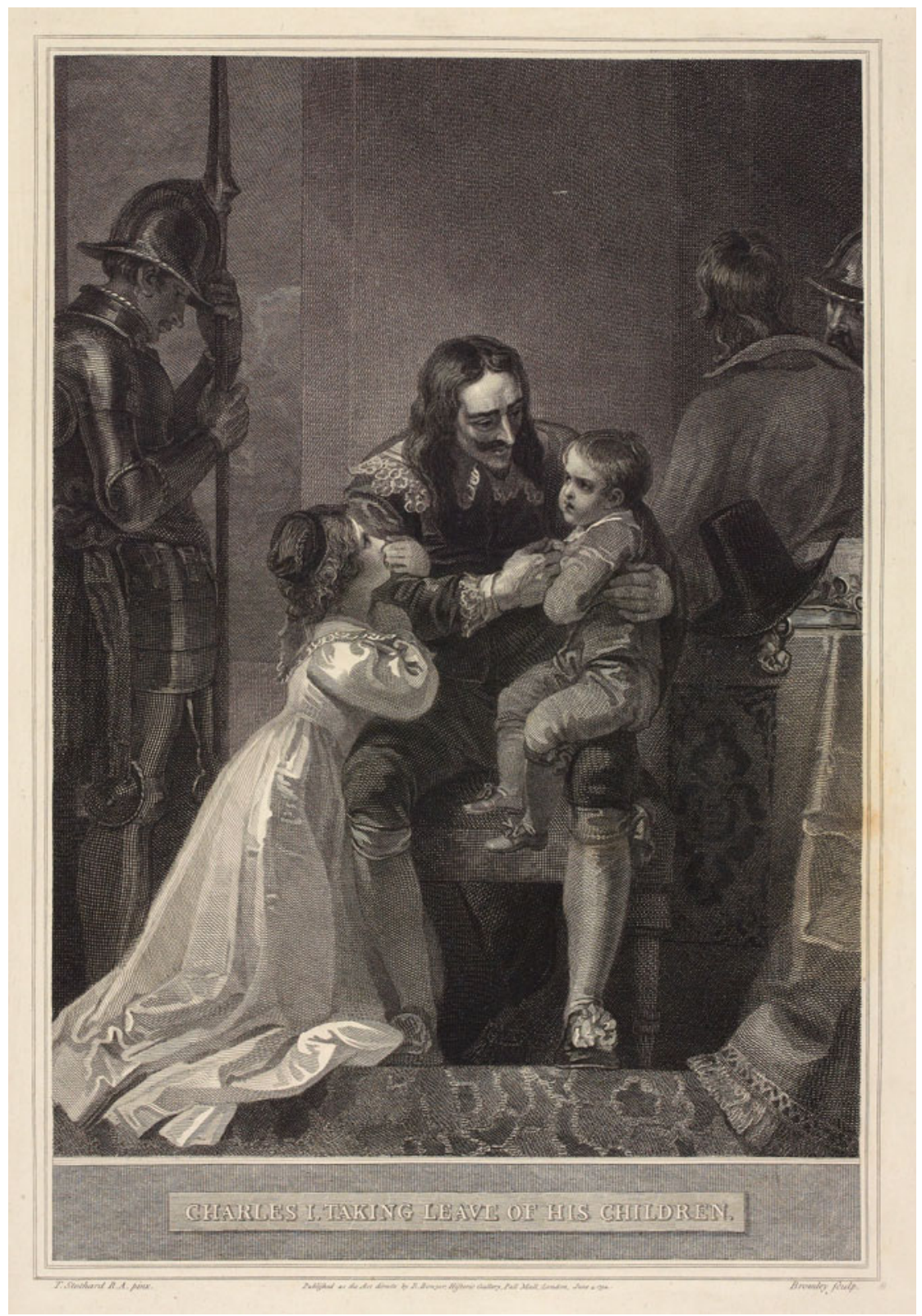

Figure 5. William Bromley after Thomas Stothard, Charles I taking leave of his children, I794. Engraving, $46.7 \times 32.2 \mathrm{~cm}$. David Hume, The history of England (folio edition) (I0 vols., London, I793-1806), X, L.C.Fol.36A(I0), National Library of Scotland. 
known not only through the extremely popular illustrated editions of Hume but also through later plagiarized copies, in books as diverse as W. H. S. Aubrey's The national and domestic history of England (1867) and Lady Calcott's Little Arthur's history of England (1856). ${ }^{43}$ The family form a pyramidal arrangement, with a stubborn-looking, cross-armed Henry perched on his father's left knee and Elizabeth sprawled over his right, looking up attentively. In a rather neat adaptation of Van Dyck's 'greate peece', Elizabeth's figure has replaced that of the infant Prince Charles at the king's side, while the young duke, balanced on his father's lap, references Henrietta Maria's supporting embrace of the Princess Mary. The original patterns of connecting gestures and gazes have been condensed, converging on the figure of Charles. The dynastic and political intimations of the prototype have also been softened so that Charles no longer scrutinizes the viewer but instead focuses upon his son, wholly occupied with his careful instruction. Gone are the crown and regalia, replaced by the king's discarded hat, his Lesser George, and a book, presumably his Bible. This arrangement and the viewer's proximity to the picture plane create a sense of intimacy, heightened by the guard standing to the right of the family group, who bows his head in acknowledgment of his intrusion on this private meeting. Like him, the viewer is drawn in, sharing in the feeling of this parting. Stothard's composition then responded both to secondary textual and primary visual sources. The tragic scene which Hume had sketched in words was now realized in image. The artist's royal protagonist complemented the historian's 'Poor King Charles', courageous in adversity and morally upright to the last; a characterization designed to evoke a sympathetic reading. ${ }^{44}$ Again, by quoting and adapting passages from Van Dyck's portraits, Stothard's painting formed a narrative with its pictorial prototypes. A sense of authenticity served as a bridge to the past, heightening the semblance of not only historical but also emotional truth. Visually emulating the sentimental voice of Hume, the pathos of the History's account was charged with immediacy.

The special relationship between word and image in Stothard's painting was characteristic of the nineteenth-century historical imagination. Written devices such as titles, quotations, and pictured words were frequently employed in order to instruct the public in the understanding of a picture. ${ }^{45}$ Writing in 1843, as the first exhibition connected to the decoration of the new palace of Westminster opened, Sir Charles Eastlake described the daily multitude who came to view the cartoons illustrating subjects from British history or literature. As secretary of the commission responsible for the project, he had directed that an abridged catalogue be made available for a penny but found that "many of the most wretchedly dressed people prefer the six penny

\footnotetext{
${ }^{43}$ See W. H. S. Aubrey, The national and domestic history of England (3 vols., London, 1867), III, p. 169; and Maria, Lady Callcott, Little Arthur's history of England (London, 1856), p. 191.

${ }^{44}$ Mark Salber Phillips, "If Mrs Mure be not sorry for poor King Charles": history, the novel and the sentimental reader', History Workshop Journal, 43 (1997), p. 113.

${ }^{45}$ Julia Thomas, Pictorial Victorians: the inscription of values in word and image (Athens, $\mathrm{OH}, 2004$ ), p. 5.
} 
one with the quotations'. ${ }^{46}$ It appears then that audiences appreciated this textual guidance that allowed them to read an image. Between 1801 and 1901, of the twenty-five paintings portraying the family of Charles I exhibited at the Royal Academy exhibitions, only three were not accompanied by a quotation or extended title. ${ }^{47}$ Of those paintings supplemented by a quotation, one author's work appears to have held a special appeal - the historical writings of Agnes Strickland. The most prominent female historian of her time, Strickland's twelve volume series, Lives of the queens of England (1840-8), proved a great commercial success, as did her later works, which included biographies of the queens of Scotland and of Tudor and Stuart princesses. ${ }^{48}$ Margaret Oliphant's commentary, written in 1855, which featured in Blackwood's Edinburgh Magazine, provides an account of the position held by these books, both as literary works and as scions of popular culture:

Instead of a slow succession of elaborate volumes, full of style and pomp, accuracy and importance, it is a shower of pretty books in red and blue, gilded and illustrated, light and dainty and personal...It is not Edward Gibbon but Agnes Strickland - the literary woman of business, and not the antique man of study - who introduces familiarly to our households in these days the reduced pretensions of the historic muse. ${ }^{49}$

Stressing the rapidity of production and the neat, gendered design of Strickland's books, Oliphant insinuates that as historical works they are both simplified and frivolous. Indeed, Strickland specialized in a form of whimsical historical biography that stylistically owed a significant debt to the romantic novel. Resisting the Whig interpretation of history, Agnes and her co-author and sister, Elizabeth, presented an alternative narrative, which was favourable to France, Catholicism, and the feminine. ${ }^{50}$ Certainly, their analysis of Henrietta Maria figured her as a devoted wife, emphasizing her private virtues and generating 'a sympathetic image of this much maligned queen'. ${ }^{51}$ Like Hume, Strickland offered her readers ample opportunity to empathize with the predicaments of historical figures. Accordingly, one anonymous critic reviewing her Stuart volume of the Lives of the queens of England in the Edinburgh Review commented: 'It would be endless to collect the innumerable

\footnotetext{
${ }^{46}$ David Robertson, Sir Charles Eastlake and the Victorian art world (Princeton, NJ, 1978), p. 65.

${ }^{47}$ The exceptions are John Bridges, King Charles I, after the last interview with his children, the Princess Elizabeth and the duke of Gloucester, 1838, oil on canvas, unlocated; Thomas Jones Barker, Charles I and Henrietta Maria, his queen, reposing after the chase in Windsor Forest, 1846, oil on canvas, unlocated; Frederick Goodall, An episode in the happier days of Charles I, 1853, oil on canvas, $99.5 \mathrm{x}$ $153.5 \mathrm{~cm}$, Bury, Bury Art Museum \& Sculpture Centre. See Graves, The Royal Academy of Arts.

${ }^{48}$ Rohan Amanda Maitzen, “"This feminine preserve": historical biographies by Victorian women', Victorian Studies, 38 (1995), pp. 371-93, at p. 372.

${ }^{49}$ Margaret Oliphant, 'Modern light literature - history', Blackwood's Edinburgh Magazine, 78, 480 (Oct. 1855), p. 437.

${ }^{50}$ Mary Spongberg, 'La reine malhereuse: Stuart history, sympathetic history and the Stricklands' history of Henrietta Maria', Women's History Review, 20 (2011), pp. 745-64, at p. 747.

${ }^{51}$ Ibid., p. 758.
} 
passages in which she has exerted her ingenuity to cast an air of romance, of pathos, or of humour, over some pointless anecdote. ${ }^{52}$

The extent to which Strickland helped shape artistic representations of the family of Charles I can be seen by close examination of Charles Lucy's painting, The parting of Charles I with his two youngest children, the day previous to his execution (1850, see Figure 6). ${ }^{53}$ The picture shows the king gazing upwards in torment, his head cradled in his hand, with his elbow propped against a window. Behind, Bishop Juxon and Princess Elizabeth cast pained glances in Charles's direction, each placing a comforting palm on the diminutive figure of the duke of Gloucester as they lead him away. An oval portrait of the absent mother, Henrietta Maria, presides over the scene. Meanwhile, just visible in the doorway, a soldier stands with his halberd ominously dissecting Van Dyck's portrait of Charles I at the hunt on the opposite wall. Comparison of the composition with Strickland's account of the last interview reveals the source for this arrangement: 'The King fervently kissed and blessed his children and called to Bishop Juxon to take them away. The children sobbed aloud; the King leant his head against the window, trying to repress his tears. ${ }^{54}$ Indeed, when the painting was exhibited at the summer exhibition of the Royal Academy in 1850 it was accompanied by a quotation virtually identical. ${ }^{55}$ Lucy's painting then is akin to a book illustration, so closely does it follow Strickland's text and tenor, expressing in visual form her retelling of the affectionate Stuart family whose 'tears and caresses' presaged its break-up. ${ }^{56}$ A review by Dante Gabriel Rossetti provides a contemporary reaction to the canvas, elaborating on its sentimental allure:

The arrangement adopted by Mr. LUCY is simple and suggestive. Bishop JUXON, holding the young prince's hand, leads him out of the antechamber, where the sentry is posted, and where VANDYCK's portrait of the King has been left hanging; the princess now on the threshold, looks back at her father once more; while the quiet head and pattering shoe of the little boy, who is evidently trying to walk faster than he is able, and the delicate manner in which he is being led by the good bishop, are peculiarly happy in their sympathetic appeal. CHARLES, standing, raises one hand to his brow; his face is bewildered with anguish. He is

\footnotetext{
52 'Article 6', Edinburgh Review, 89, 180 (Apr. 1849), p. 437.

${ }^{53}$ Hartlepool Museum currently describes this painting as English School (nineteenth century). However, stylistic analysis shows the same broad handling of paint and soft tonal definition characteristic of Lucy's other known works. The striking similarity of the composition to a description of Lucy's painting in a review of the 1850 Royal Academy Exhibition also confirms my reattribution; see Dante Gabriel Rossetti, 'The Royal Academy exhibition', The Critic, 9 (1850), p. 254.

${ }^{54}$ Agnes Strickland, The lives of the queens of England (12 vols., London, 1840-8), VIII, p. 126.

55 'The King fervently kissed and blessed his children, then suddenly rising, called to Bishop Juxon to take them away; the children sobbed aloud. The King, standing, leant against the window; trying to repress his tears' - see Graves, The Royal Academy of Arts, V, p. 109.

${ }^{56}$ Strickland, The lives of the queens of England, VIII, p. 126.
} 


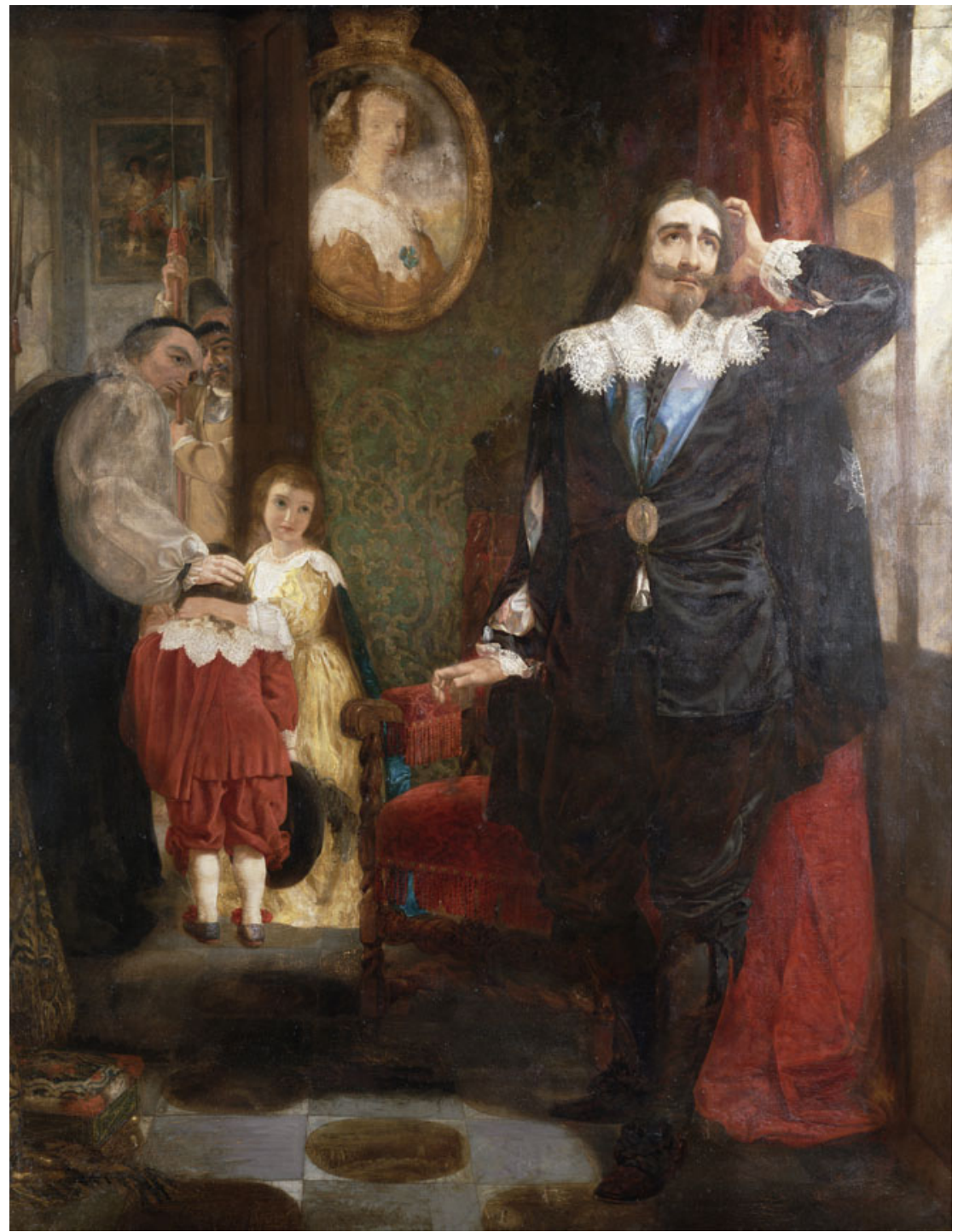

Figure 6. Charles Lucy, The parting of Charles I with his two youngest children, the day previous to his execution, 1850. Oil on canvas, $230 \times 178 \mathrm{~cm}$. Hartlepool Museum Service, UK (C) Hartlepool Museum Service /Bridgeman Images.

turning unconsciously against the window and the hand which has just held those of his children for the last time, is quivering helpless to his side. $^{57}$

\footnotetext{
${ }^{57}$ Rossetti, ‘The Royal Academy exhibition', p. 254.
} 
Extending Hume's sympathetic presentation of the past, Strickland's writing merged historical narrative with melodrama. In her account, the 'pious consolations' described by Hume became 'a passion of tears'. ${ }^{58}$ Similarly, instead of the quiet sentiment of Stothard's composition, Lucy's canvas resonates with feeling. Certainly, the review focuses on the emotional effects of the painting and on the interiority of its actors - the king's suffering, his daughter's concern, his son's guileless innocence. For Rossetti, the artist had eschewed the 'mere parade of truthfulness' and created a work of unmitigated veracity. ${ }^{59}$ In both word and image, then, history has become domesticized, accentuating the intimate and affective; reducing and reinscribing the public and political. Again, the artist has made connections to seventeenth-century portrayals. Enlisting the original imagery in his story-telling, Lucy underscored the changed circumstances of the Stuarts and enhanced the scene's pathos. These nineteenth-century pictures and their counterparts then realized the changing tone of historical writing and comprised a visual historiography of the Caroline royal family. Materializing shifting historical perceptions, they sought to involve the viewer in moments of emotional poignancy. Conflating the borders between past and present, sympathy for distant suffering inspired a sense of historical proximity.

\section{IV}

Commenting on her contemporaries' tendency to look back into history as a means of explaining the dilemmas of the present, Margaret Oliphant observed: 'We recollect that these old heroes had not a thought of the nineteenth century under these grim visors of theirs, nor the smallest intention of benefiting us by their blunders and mischances, their breaking of heads and spears, their squabbles with kings and commons. ${ }^{60}$ Yet, despite Oliphant's caveat, the allure of the stricken Stuarts lay precisely in the apparent parallels between the fractures of the seventeenth century and the stresses which afflicted nineteenthcentury society. ${ }^{61}$ The aftershocks of the divisions of the Civil War ran deep and Victorian historical sympathies fell along contemporary political lines. Elaborating on this correlation, a reviewer from The Standard described an average audience at The Lyceum's 1872 staging of Charles I: 'One third, it may be said were staunch Royalists, about a half were interested in the play and not in politics present or past...and only a small minority were devoted Liberals, jealous of every touch that seemed to blot the fair fame of the Radical idol [Cromwell]. ${ }^{62}$ Playing upon this sense of historic communality, artists repeatedly reimagined the conflicts between Royalist and Roundhead as a pattern of the present which might also convey a revelation for the future.

\footnotetext{
${ }^{58}$ Hume, The history of England (folio edition), X, p. 469; Strickland, The lives of the queens of England, VIII, p. 125.

${ }^{59}$ Rossetti, 'The Royal Academy exhibition', p. 254.

${ }^{60}$ Oliphant, 'Modern light literature - history', p. 438.

${ }^{61}$ Strong, And when did you last see your father?, p. 141; Lang, The Victorians and the Stuart heritage, p. 1.

62 'Charles I and Cromwell', The Standard, 15049, 23 Oct. 1872, p. 3.
} 
Resonances were compounded as the Caroline royal family was gradually subsumed into the Victorian cult of domesticity. Nineteenth-century family life was deemed more than a social institution; it was at the heart of civilized society. ${ }^{63}$ The public were not only conscious of inheriting this fixation but actively sought out historical precedents for their own domestic cares. ${ }^{64}$ The Caroline royal family provided one such precedent. The Stuarts had encouraged their subjects to take an interest in their family life, blurring boundaries between public and private and fostering affective ties between sovereign and subject. ${ }^{65}$ Over two centuries later, their portraits continued to strike a chord. Stuart domestic messages were accepted, appreciated, and extended. In line with nineteenth-century models, Charles I became an affectionate and tender father, Henrietta Maria a supportive and obedient wife. Yet the unfortunate Stuarts had now become an object lesson, a conservative warning of the personal tragedies born of political unrest. This theme had been partially explored in the preceding century. Jean Raoux's painting of 1722, depicting the king's last meeting with his children, had been reproduced in a number of eighteenth-century British prints. ${ }^{66}$ Nineteenth-century historical genre paintings, however, intensified this threat. Audiences were presented with a projection of their own home lives and encouraged to share in the trauma of domestic rupture. Artists exploited affinities and encouraged a strong identification with the past.

This partisan approach to history is palpable in Daniel Maclise's An interview between Charles I and Oliver Cromwell (1836, see Figure 7). The canvas depicts a fictional meeting between the king and the army's senior officers. Represented in profile, Cromwell is arrayed-rather implausibly-in full armour, with his scabbarded sword resting at his side. His likeness is loosely based on Robert Walker's portrait. ${ }^{67}$ Cast as a figure of military might, he sits, shadowed, focusing his intense gaze on the royal captive. Behind him, Commissionary General Ireton, Cromwell's son-in-law, cups his chin in his hand as he records the proceedings, while the figure of Commander-in-Chief Thomas Fairfax emerges from the gloomy background. In contrast, the melancholic Charles (again closely modelled on Van Dyck's portraits) is illuminated;

\footnotetext{
${ }^{63}$ Wohl, 'Introduction', p. 10.

${ }^{64}$ Karen Chase and Michael Levenson, The spectacle of intimacy: a public life for the Victorian family (Princeton, NJ, and Oxford, 2000), p. 13.

${ }^{65}$ Catriona Murray, Imaging Stuart family politics: dynastic crisis and continuity (Abingdon and New York, NY, 2017), p. 42.

${ }^{66} \mathrm{See}$, for example, Anon., The marriage, wars, suffering and death of the royal martyr, King Charles the First, c. 1725-34, engraving, 63.5 x $97.0 \mathrm{~cm}$, London, Royal Collection; Anon., At this sad scene who can from tears refrain?, c. 1750, etching, 16.2 x $10.2 \mathrm{~cm}$, London, British Museum; and Anon., The king taking leave of his children, c. 1750, etching, 24.4 x $15.6 \mathrm{~cm}$, London, British Museum. Raoux's painting was commissioned as part of a sequence of historical pictures illustrating the life of Charles I, which were later engraved and issued in 1728 as a set of ten large-scale prints-see David H. Solkin, 'The English Revolution and the revolution of history painting: the Bowles Brothers' "Life of Charles I"', in Mark Hallett, Nigel Llewellyn and Martin Myrone, eds., Court, country, city: British art and architecture, 1660-1735 (New Haven, CT, and London, 2016), pp. 263-86.

${ }^{67}$ See Robert Walker, Oliver Cromwell, c. 1649, oil on canvas, 125.7 x $101.6 \mathrm{~cm}$, London, National Portrait Gallery.
} 


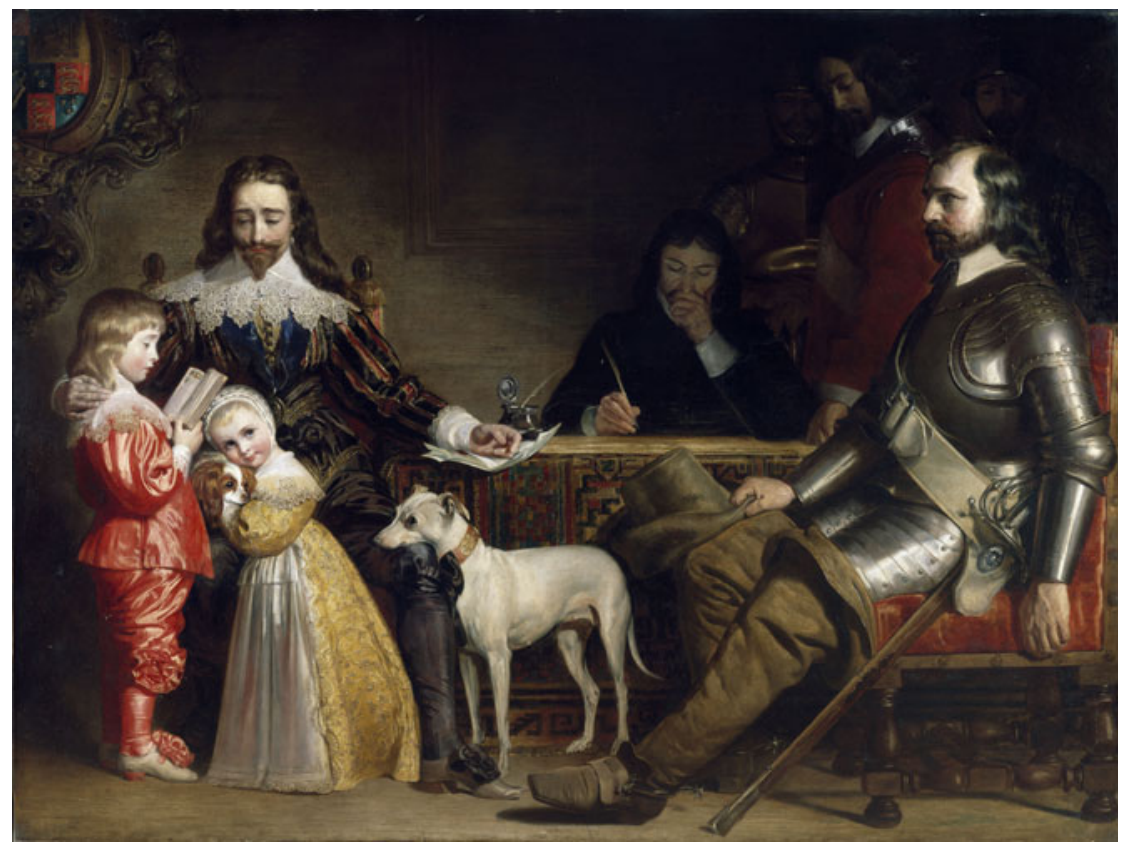

Figure 7. Daniel Maclise, An interview between Charles I and Oliver Cromwell, I836. Oil on canvas, $184 \times 235 \mathrm{~cm}$. Photo (c) National Gallery of Ireland NGI.I208.

animals and children alike gather to his bosom. One hand rests on an opened and discarded letter, while his other arm sits on the shoulder of his son, who reads from the Bible. The chubby-faced, rosy-cheeked figure of Elizabeth snuggles into her pet dog, seemingly unaware of the import of the conference. This visual distinction between uneasy insight and artless innocence was identified by a contemporary critic, who observed that 'the unconscious playfulness of the little prince and princess in their gay apparel, are [sic] well contrasted with the dejected looks and sombre habiliments of their unfortunate parent'. ${ }^{68}$ In fact, the effect was carefully contrived. The appearance of the young prince, whom the artist identifies as James, duke of York, is drawn from Van Dyck's portrait of the seven-year-old second duke of Buckingham (1635, see Figure 8). ${ }^{69}$ Maclise has even appropriated the red and gold clothing, which had been employed so strikingly in the original composition of the duke and his brother, adapting it for the dress of the prince and his sister. Elizabeth's likeness derives from an actual portrait of her as a toddler, contained within Van Dyck's The five eldest children of Charles I (1637, see Figure 9). James and Elizabeth, however, would have been around fifteen and thirteen years of age respectively during the king's negotiations with the army. Maclise has consciously infantilized this pair of princes, reinforcing their childish vulnerability

\footnotetext{
68 'Fine Arts', The Gentleman's Magazine: and Historical Review (July 1836), p. 72.

${ }^{69}$ Graves, The Royal Academy of Arts, V, p. 153.
} 


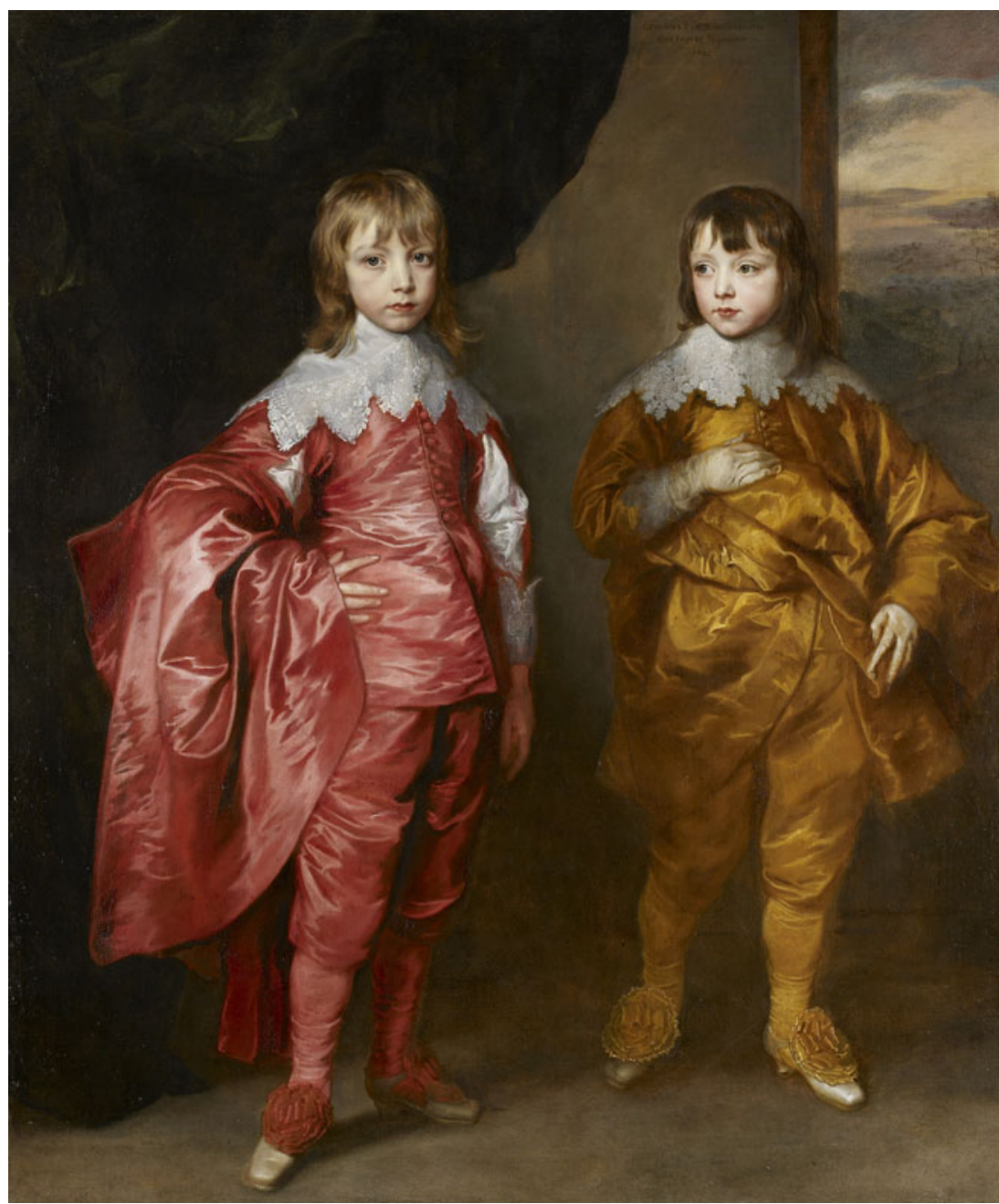

Figure 8. Anthony van Dyck, George Villiers, second duke of Buckingham and Lord Francis Villiers, 1635. Oil on canvas, 186.7 x $137.2 \mathrm{~cm}$. Royal Collection Trust. () Her Majesty Queen Elizabeth II 2021.

and emphasizing the protective, nurturing role of their father. In this touching image of familial devotion, Charles has become a personification of benevolent paternalism. The artist's composition, then, visually contrasts two regimes and two forms of authority. Its black-and-white rendering of the past encouraged nineteenth-century audiences to see reflections on the canvas and to distinguish historical alignments.

The intensity of Cromwell's unreturned glare, caught in a moment of rumination, echoes the penetrating gaze contained in another historical genre painting. Paul Delaroche's depiction of a later episode in the interconnected histories of these two men, Cromwell and Charles I, pictured the regicide 


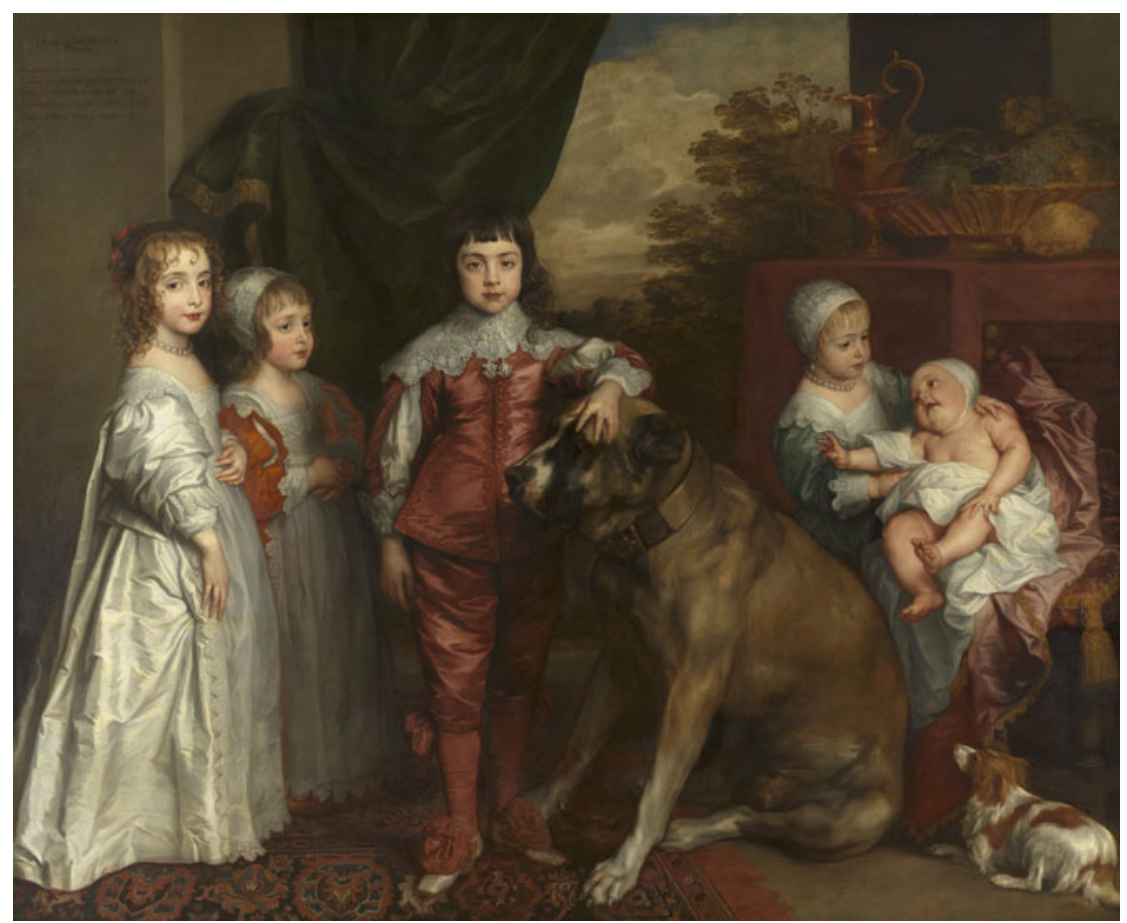

Figure 9. Anthony van Dyck, The five eldest children of Charles I, 1637. Oil on canvas, $163.2 \times 198.8 \mathrm{~cm}$. Royal Collection Trust. (C) Her Majesty Queen Elizabeth II 202I.

contemplating the lifeless body of the king. ${ }^{70}$ The French artist was instrumental in promoting English Civil War subjects to an international audience and his influence on the development of the British school would be decisive. ${ }^{71}$ He was working on his composition in 1830, when Maclise was in Paris, but it was also known through Louis Pierre Henriquel-Dupont's aquatint (c. 1833, see Figure 10). ${ }^{72}$ Certainly, Oliver's boots and the chair upon which he sits in Maclise's picture owe a clear debt to its precursor. To the French viewer, Delaroche's painting was layered with historical parallels. Charles I could be read both as a portent of Louis XVI and of the more recently ousted Bourbon monarch, Charles X, while Cromwell suggested both Napoleon and the newly proclaimed king, Louis-Philippe. ${ }^{73}$ It may well be that Maclise intended the searching, brooding gaze of his Cromwell to rhetorically prefigure Delaroche's conception of the last confrontation. A pictorial serialization of

\footnotetext{
${ }^{70}$ See Paul Delaroche, Cromwell and Charles I, 1831, oil on canvas, 225 x 292 cm, Nîmes, Musée des Beaux-Arts.

${ }^{71}$ Bann, Scenes and traces of the English Civil War, p. 15.

${ }^{72}$ W. Justin O'Driscoll, A memoir of Daniel Maclise, B.A. (London, 1871), p. 44.

${ }^{73}$ Martin Miesel, Realisations: narrative, pictorial and theatrical arts in nineteenth-century England (Princeton, NJ, 1983), p. 232.
} 


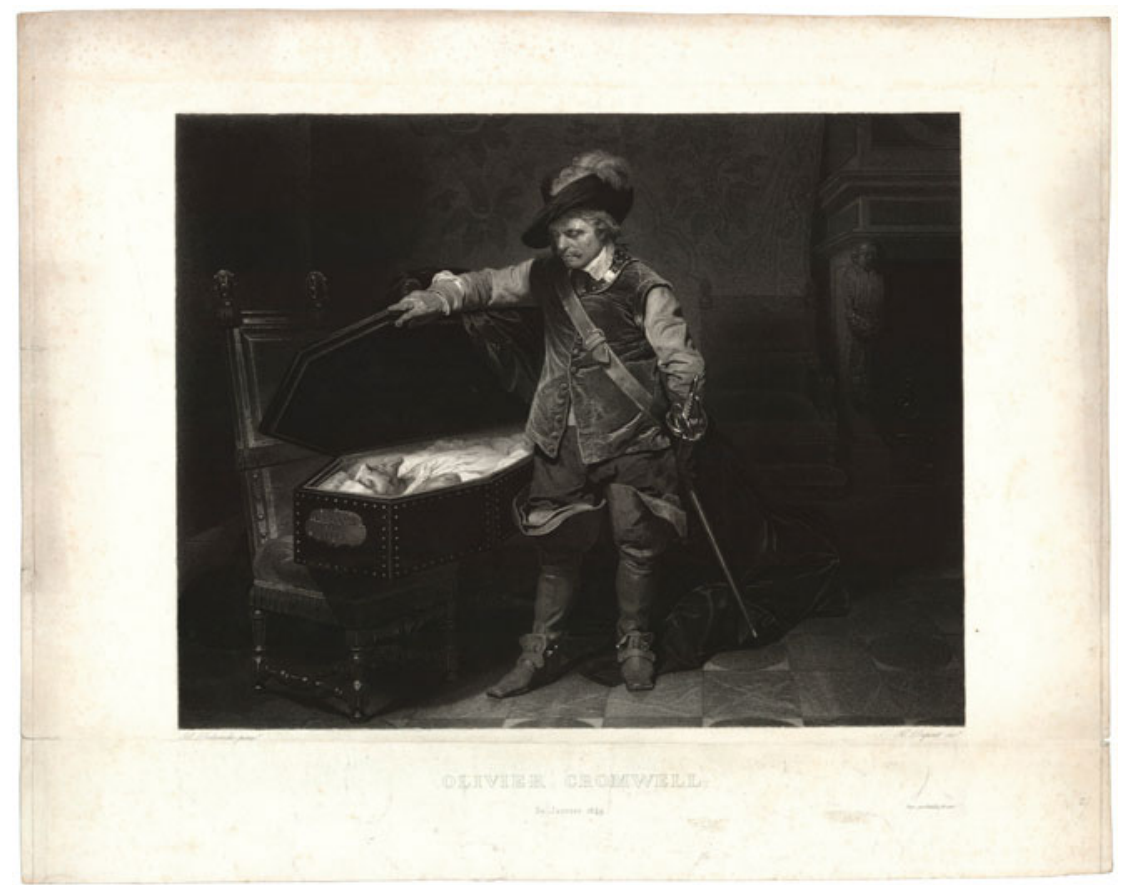

Figure 10. Louis Pierre Henriquel-Dupont after Paul Delaroche, Cromwell and Charles I, c. I833. Aquatint, $43.3 \times 55 \mathrm{~cm}$. (C) National Portrait Gallery, London.

history is again apparent, a sequence of momentous episodes somehow connected. In adapting this motif, the composition opens a window into the interiority of the protagonists. However, whereas there is an intentional ambiguity to the French painter's representation of the final meeting, Maclise instead directs the understanding of the viewer. The extended quotation, which accompanied his canvas, when it was exhibited at the Royal Academy summer exhibition, hints at the futility of the negotiations and the incompatibility of these two ideologies: "After the surrender of Charles I from the Scottish camp to the English commissioners, many interviews took place between that prince and the leaders of the independent party, with a view to some final accommodation...They closed, finally, in a rejection by the king of the terms proposed. ${ }^{74}$ Maclise's self-penned passage stresses the breakdown of the talks, brought to an end by the king without settlement. ${ }^{75}$ In his painting, Charles's later fate is inevitable and the monarch is figured as reconciled to his end. Martin Miesel has observed that visions of the "happy domesticity of the royal family, threatened with imminent disruption by cruel, venal and

\footnotetext{
${ }^{74}$ Graves, The Royal Academy of Arts, V, p. 153.

${ }^{75}$ The sources for Maclise's text are unclear. An autograph document containing the quotations that accompanied both of the paintings that he exhibited at the Royal Academy Summer Exhibition in 1836 is in the collections of the Folger Shakespeare Library, Washington DC, MS Y.d828.
} 
ambitious men, became the essential situation in the Tory Victorian version of the drama of King Charles, ${ }^{76}$ The widespread circulation in print of similar scenes ensured that this message extended beyond the crowds of the Royal Academy exhibitions. ${ }^{77}$ Maclise was both a Tory and a royalist. ${ }^{78}$ His composition warned of the dangers of radicalism, drawing attention to the family as innocent victims of this erosion of social harmony. Clearly delineating two opposing styles of governance, it exhorted audiences to view themselves in the imperilled Stuart domestic unit. The Caroline royal family was, therefore, charged with a potent symbolism, formed through a perceived relationship between subject and viewer. Historical proximity was enhanced by contemporary resonances within this unfolding drama, promoting affinity and rapport.

\section{V}

Writing in her journal during a stay in the Scottish Highlands in 1873, Queen Victoria mused: 'Stuart blood is in my veins and I am now their representative and the people are as devoted and loyal to me as they were to that unhappy race. ${ }^{79}$ In reality, the queen's ancestral claims were a fiction; a rather inventive reading of British royal genealogy. ${ }^{80}$ However, her statement indicates that the monarch shared with her subjects a deep connection to the Stuart past - a sense of direct inheritance. Indeed, when artists depicted the domestic happiness of Victoria and Albert or their growing brood, rich with allusions to Van Dyck, they pictorially augmented this claim to kinship. Like the Stuarts, however, the sentimental bliss of the Victorian royal family was carefully constructed. ${ }^{81}$ Both the portraits of Anthony van Dyck and of Franz Xavier Winterhalter aspired to create a bond between royalty and the people - to bring the first family of the realm closer to their public. Nineteenth-century historical genre paintings of Charles I and his family were also designed to create proximity between viewer and subject, bridging the rifts between past and present. Historical distance diminished through a manifold visual experience.

\footnotetext{
${ }^{76}$ Miesel, Realisations, p. 240.

${ }^{77}$ Ibid., p. 4. See, for example, John Rogers's engraving after Samuel Woodforde, The interview of Charles I with his children, c. 1810s, 17.7 x $22.2 \mathrm{~cm}$, London, British Museum; Samuel Bellin's engraving after John Bridges, King Charles I, after the last interview with his children, the Princess Elizabeth and the duke of Gloucester, 1841, 60.5 x $46.7 \mathrm{~cm}$, London, National Portrait Gallery; Harvey Orrin Smith's engraving after Frederick Goodall, An episode in the happier days of Charles I, c. 1853, 15 x $22.7 \mathrm{~cm}$, London, British Museum; Peter Lightfoot's engraving after William Frederick Yeames, The peril of the Queen Henrietta Maria, 1869, 24.7 x $33.8 \mathrm{~cm}$, London, British Museum; an anonymous lithograph after Margaret Isabel Dicksee, The children of Charles I, c. 1901, 16.5 x $21.5 \mathrm{~cm}$, Carisbrooke, Carisbrooke Castle Museum.

${ }^{78}$ John Turpin, 'Maclise and the Royal Academy', in Peter Murray, ed., Daniel Maclise, 1806-1870: romancing the past (Cork and Oysterhaven, 2008), p. 148.

${ }^{79}$ Victoria, queen of Great Britain, More leaves from the journal of a life in the Highlands from 18621892 (London, 1884), p. 255.

${ }^{80}$ Sophie Gilmartin, Ancestry and narrative in nineteenth-century British literature: blood relations from Edgeworth to Hardy (Cambridge, 1998), p. 59.

${ }^{81}$ Simon Schama, 'The domestication of majesty: royal family portraiture, 1500-1850', Journal of Interdisciplinary History, 17 (1986), pp. 155-83, at p. 158.
} 
Artists and audiences strove to recapture, recreate, and relive the domestic bonds and fractures of the seventeenth century. They did so by drawing upon alignments and connections - temporal, visual, and verbal. These relationships were integral to the cognitive, emotional and associative responses of the viewer. Establishing an episodic narrative, these canvases initiated processes of recollection and recognition, they reflected sympathetic historiographies, and they encouraged a shared community with the pictorial protagonists. Historical proximity was engendered through a multi-layered visual encounter that was active and participatory. As Phillips has skilfully shown, all histories locate their audience in relation to the past. I have sought to contribute further dimensions to the understanding of historical positioning by mapping out how audience responses can coincide and converge to produce a familiarized past. Of course, this intimate view was also a distorted one. It was shaped with hindsight and coloured by nostalgia. Historical difference, as well as distance, was negotiated, moderated, and diminished to aid understanding. This was history as spectacle, an immediate but incomplete vision.

Competing interests. The author declares none.

Cite this article: Murray C (2022). Reimagining the Family of King Charles I in Nineteenth-Century British Painting. The Historical Journal 65, 1035-1059. https://doi.org/10.1017/S0018246X21000807 